\title{
¿EN TIERRA DE CACIQUES! LIDERAZGOS POPULISTAS Y DEMOCRACIA EN ECUADOR
}

Flavia FreidenberG*

Resumen

El objetivo de este trabajo es explorar las características del populismo a partir de la experiencia de Ecuador, uno de los países de América Latina que ha tenido más procesos de este tipo. La idea es identificar semejanzas en el modo en que se ejerce el estilo de liderazgo populista a partir de cuatro casos: José María Velasco Ibarra, Abdalá Bucaram Ortiz, Álvaro Noboa Pontón y Rafael Correa, a pesar de las diferencias existentes entre esos líderes políticos. El argumento es que, a diferencia de las aproximaciones prevalecientes en la literatura ecuatoriana, el populismo debe entenderse como un estilo de liderazgo que se da entre líder-seguidor, el cual tiene una serie de características específicas que se mantienen en el tiempo, más allá de las diferencias contextuales y sistémicas.
Palabras clave: populismo, estilo de liderazgo, democracia representativa, Correa, Bucaram, Velasco Ibarra, Noboa Pontón.

\section{IN LAND OF CHIEFTAINS! POPULIST LEADERSHIP AND DEMOCRACY IN ECUADOR}

\section{Abstract}

The objective of this paper is to explore the characteristics of populism from the experience of Ecuador, one of the countries in Latin America that has had more processes of this type. The idea is to identify similarities in the way that the populist style of leadership is exercised from four cases despite the existing differences between these political leaders: Jose Maria Velasco Ibarra, Abdala Bucaram Ortiz,

* Investigadora del Instituto de Investigaciones Jurídicas de la Universidad Nacional Autónoma de México (UNAM), México D.F., México. ffreidenberg@gmail.com

Recibido: 25 de agosto de 2014 / Modificado: 22 de enero de 2015 / Aceptado: 1 de marzo de 2015.

Para citar este artículo

Freidenberg, F. (2014). ¡En tierra de caciques! Liderazgos populistas y democracia en Ecuador. OPERA, 16, pp. 99-13. DOI: 10.18601/16578651.n16.07. 
Alvaro Noboa Ponton, and Rafael Correa. The argument is that, unlike the prevailing approaches in Ecuadorian literature, populism must be understood as a style of leadership that occurs between leader and follower, which has a series of characteristics that are maintained throughout time, regardless of the contextual and systematic differences.

Key words: Populism, leadership style, representative democracy, Correa, Bucaram, Velasco, Noboa Porton.

\section{INTRODUCCIÓN}

El objetivo de este trabajo es describir uno de los fenómenos más importantes de la historia política contemporánea de Ecuador desde las primeras décadas del siglo xx: el populismo. Los ecuatorianos aprendieron que la democracia se hacía en los espacios públicos más que en las instituciones y que, para ello, no se requería de densos vínculos programáticos ni de organizaciones partidistas, sino de la presencia de un líder fuerte que canalizara sus demandas. Desde la década de los treinta, diversos movimientos o partidos vinculados a este modo de ejercer la política han obtenido en los comicios presidenciales más del $20 \%$ del apoyo electoral, lo que ha supuesto una presencia importante en el sistema de partidos del país andino.

José María Velasco Ibarra, Assad Bucaram, Jaime Roldós, Abdalá Bucaram Ortiz, Álvaro Noboa Pontón o Rafael Correa fueron algunos de los líderes que han ejercido la política de esta manera y han sido definidos por periodistas, analistas políticos y estudiosos como "populistas". Si bien sus liderazgos presentan rasgos diferentes entre unos y otros, y responden a coyunturas críticas diferenciadas, hay un conjunto de elementos que parecen estar presentes en su manera de relacionarse con sus seguidores y de ejercer la representación política.

Este trabajo describe el modo en que el líder y sus seguidores se relacionan entre sí, esto es, el estilo de liderazgo de algunos políticos ecuatorianos, con la intención de identificar semejanzas entre ellos y de contribuir al debate sobre la naturaleza de un concepto difícil de definir ${ }^{2}$. A pesar de lo extendido de esta idea en el imaginario político ecuatoriano, y de algunas escasas excepciones ${ }^{3}$, la literatura

1 Ver los excelentes estudios sobre Velasco Ibarra de Quintero (1978), Burbano de Lara (1998), De la Torre (2000), o Moreano y Donoso (2006). Sobre el cFp y sus líderes, ver Martz (1980 y 1983), Menéndez Carrión (1986), Fernández y Ortiz (1988), Guerrero Burgos (1994) o Moreano y Donoso (2006). Sobre el roldosismo ver los estudios de El Burbano de Lara (1998), De la Torre (1996; 1999), Freidenberg (2003), Moreano y Donoso (2006) o Conaghan (2008b). Entre los trabajos sobre Rafael Correa en clave populista destacan los de Conaghan (2008a), Conaghan y De la Torre (2008), De la Torre (2009), Moncayo (2010), De la Torre (2012), Freidenberg (2008c).

2 El término populismo es uno de los más complicados de definir en las ciencias sociales. Una discusión sobre diferentes estrategias de definición del populismo, en Freidenberg (2012).

3 Los trabajos publicados por De la Torre o los de Conaghan también emplean una aproximación similar, aunque no hacen explícito su enfoque como estilo de liderazgo. 
no ha centrado su atención en el populismo como un estilo de liderazgo sino que han prevalecido visiones más como movimiento o régimen político, o incluso manifestaciones de cultura política.

La investigación explora el populismo desde la perspectiva de cómo se ejercen los liderazgos, el universo simbólico que une a los líderes con sus seguidores y los efectos que esa relación tiene sobre el funcionamiento de las instituciones democráticas en Ecuador. Este es un ejercicio de política comparada, tanto en términos diacrónicos, comparando experiencias en el tiempo, como en términos sincrónicos, analizando las semejanzas y diferencias entre diversos líderes políticos a los que se denomina como populistas.

El argumento principal es que las semejanzas en el estilo de liderazgo de Velasco Ibarra, Bucaram Ortiz, Noboa Pontón y Correa Delgado (Freidenberg 2008) están en a) el modo directo y personalista en que se relacionan con sus seguidores; b) la tendencia a carecer de mecanismos de intermediación, de minimizar su existencia cuando están estructurados o de anteponer ese vínculo directo por encima de las organizaciones que han creado; c) la interpelación discursiva del individuo como parte de un colectivo (perdiendo su condición de individuo) y en oposición al enemigo de turno del líder, junto a d) la exaltación del discurso antipartidista y e) al uso de estrategias de movilización de tipo clientelar que le permiten mantener e incluso incrementar la base de apoyo del proyecto político que se defiende. Entre Velasco Ibarra, Bucaram y Correa hay, además, similitud en las dotes carismáticas, entendido esto en términos weberianos de un liderazgo excepcional, a diferencia de Noboa, que no cuenta con esta condición.

Estas semejanzas no ocultan las diferencias entre estos líderes populistas. Noboa y Correa representan modelos bastantes distintos de país, ya sea por su extracción social, sus posicionamientos ideológicos, la visión del papel de Ecuador en el escenario político, el tipo de relación con la clase política (aun cuando los dos son outsiders) y su visión respecto a la inserción del país en el ámbito económico internacional. En ese esquema, Noboa se presentó como una opción de derecha, que encarna los intereses de los empresarios y de sectores sociales oligárquicos de Guayaquil, contrarios a la hegemonía socialcristiana y roldosista, mientras que Correa se benefició del discurso de la revuelta forajida y de la protesta ciudadana contra un sistema de partidos en crisis, dando cuenta de las magras capacidades de adaptabilidad de estos frente a los desafíos de representación ciudadana.

Si bien las tres opciones actúan como actores antipartidistas, existen diferencias respecto al papel que el Partido Roldosista Ecuatoriano ha tenido en la articulación del liderazgo de Bucaram con los líderes locales (Freidenberg 2003); elemento que no es visible en el Partido Renovador Institucional Acción Nacional (PRIAN) o en el Movimiento País. Finalmente, la base social a la cual se apela discursivamente varía de un liderazgo a otro. En el caso de Correa, el pueblo son los ciudadanos y el enemigo los partidos y la institucionalidad vigente, mientras que para Velasco Ibarra, Bucaram y Noboa el pueblo son sectores pobres, marginados, a quienes puede movilizar a través de redes clientelares, 
aun cuando sus apoyos no provengan solo de esos sectores marginales sino también de aquellos otros que dicen combatir: la oligarquía.

El trabajo se estructura en cinco partes. Primero, se presenta la metodología a partir de la cual se aborda el estudio de los diferentes liderazgos. Segundo, se aplica dicha matriz a un ejemplo de populismo clásico como el de José María Velasco Ibarra. Tercero, se analiza otro ejemplo de populismo de la década de los noventa, como el de Abdalá Bucaram Ortiz. Cuarto, se analizan dos casos de liderazgos populistas contemporáneos, como el de Álvaro Noboa Pontón y el de Rafael Correa. Finalmente, a modo de conclusión, se reflexiona sobre la relación entre democracia y populismo, con la intención de pensar algunas tensiones existentes entre esta forma de representación delegativa y el pluralismo político.

\section{METODOLOGÍA. ¿CÓMO IDENTIFICAR UN LIDERAZGO POPULISTA?}

La propuesta para explorar las diferentes manifestaciones populistas se materializa a partir de una matriz analítica, con una serie de dimensiones que permiten observar esos liderazgos (Freidenberg 2007). Las dimensiones que se emplean en el análisis son:

a) El contexto en el que surge el liderazgo, donde se analiza la situación política y económica internacional y nacional en la que el líder inicia su relación con los seguidores, llega al poder o conduce a su movimiento, así como también se explora el mecanismo que emplea para acceder a las instituciones democráticas, ya sea a través de elecciones competitivas, semicompetitivas, un golpe de Estado o designación presidencial.

b) La naturaleza del estilo de liderazgo, donde se explora el modo en que se da la relación entre el líder y sus seguidores, señalando el tipo de vinculación; la presencia o ausencia de una organización que medie la relación y el modo en que lo hace (como un instrumento del líder o como una organización autónoma).

c) La base social de apoyo y el tipo de movilización; en esta dimensión se busca identificar las características reales y simbólicas de los seguidores, el modo en que perciben al liderazgo, los grupos que a través de alianzas o simples acuerdos coyunturales sostienen al líder, a su partido o su gobierno. Además, se describe el modo en que el líder y su partido o movimiento movilizan a los grupos que les siguen, ya sea de arriba hacia abajo o a la inversa, por el flujo de las bases hacia el líder.

d) Estrategias discursivas que se utilizan para legitimar la acción política, donde se explora el modo en que se pretende dar contenido a la categoría "pueblo" y las características de los grupos que son usados discursivamente por el líder como "oposición" al pueblo.

e) El contenido de las politicas económicas y sociales; a través de esta dimensión se estudia el tipo de políticas que estos líderes llevan a la práctica. La idea es ver en qué medida todos los populistas implementaron las mismas políticas o si hay diferencias entre ellos en relación con el contenido de las mismas. 
f) El modo en que se da su salida del poder, significa observar cómo terminó el líder su periodo de gobierno, si lo hizo al finalizar su mandato de manera natural, si pretendió quedarse en el poder y cuál ha sido el mecanismo que se empleó en el caso de que lo quitaran del poder (golpe de Estado, autogolpe, juicio político por el Congreso, revolución, muerte, exilio u otro). En el caso de los movimientos políticos, se refiere a las situaciones en las que el líder terminó su acción política (muerte, abandono, renuncia, exilio, autoexilio, juicio político, golpe de Estado, entre otros).
El estilo de liderazgo es el dominio primario que puede encontrarse en diferentes tipos de gobiernos y movimientos a los que se suele denominar como populistas, toda vez que sus políticas, el contexto en el que emergieron, la base social de apoyo o el modo en que salieron del poder pueden variar. Son las cualidades de ese líder, la creencia de los seguidores y la interpelación a lo popular, de manera dicotómica frente a un "otro", lo que constituye la parte central de la relación, como se podrá constatar en los diferentes capítulos de este libro.

TABLA 1. RESUMEN DE DIMENSIONES E INDICADORES

\begin{tabular}{|c|c|c|}
\hline Dimensión & Preguntas por responder & Indicadores \\
\hline $\begin{array}{l}\text { Contexto en el que } \\
\text { surge el liderazgo }\end{array}$ & $\begin{array}{l}\text { ¿Hay crisis que fomenta su emergencia? } \\
\text { ¿Cuál es el tipo de crisis? } \\
\text { ¿Accede al poder a través de métodos de- } \\
\text { mocráticos? }\end{array}$ & $\begin{array}{l}\text { Crisis económica internacional/nacional. } \\
\text { Crisis social. } \\
\text { Modo en que llega al poder: elecciones } \\
\text { competitivas, semicompetitivas, golpe de } \\
\text { Estado, dedazo. }\end{array}$ \\
\hline $\begin{array}{l}\text { Modo de relación } \\
\text { líder-seguidor }\end{array}$ & $\begin{array}{l}\text { ¿Cómo es el estilo de liderazgo? } \\
\text { ¿Existe intermediación organizada? }\end{array}$ & $\begin{array}{l}\text { Paternalista o no, personalista o no. } \\
\text { Carismático o no. Diferentes grado de ca- } \\
\text { risma. } \\
\text { Existe partido, sindicato u otras organiza- } \\
\text { ciones. }\end{array}$ \\
\hline $\begin{array}{l}\text { Base social de apoyo } \\
\text { y tipo de movilización } \\
\text { de los seguidores por } \\
\text { parte del líder }\end{array}$ & $\begin{array}{l}\text { ¿Quiénes son los seguidores? } \\
\text { ¿Cómo son, qué intereses tienen? } \\
\text { ¿Cómo se les moviliza? } \\
\text { ¿Qué recursos emplean para motivarlo? }\end{array}$ & $\begin{array}{l}\text { Grupos (o clases) que apoyan al líder } \\
\text { Intereses que defienden. } \\
\text { Tipo de movilización: espontánea (de abajo } \\
\text { hacia arriba) o inducida (de arriba hacia aba- } \\
\text { jo). Actores que movilizan: partido, Estado, } \\
\text { sindicatos. }\end{array}$ \\
\hline $\begin{array}{l}\text { Estrategias y conteni- } \\
\text { do discursivo del líder }\end{array}$ & $\begin{array}{l}\text { ¿A quién apelan en el discurso? } \\
\text { ¿Quién es el pueblo? ¿Quiénes y cómo son } \\
\text { los seguidores en el discurso? } \\
\text { ¿Quiénes son los enemigos? ¿Cómo se los } \\
\text { caracteriza? }\end{array}$ & $\begin{array}{l}\text { Al "pueblo", a los "sectores oligárquicos", a los } \\
\text { "ciudadanos", a los "individuos" } \\
\text { Referente colectivo frente a referente indi- } \\
\text { vidual. }\end{array}$ \\
\hline
\end{tabular}




\begin{tabular}{|l|l|l|}
\hline \multicolumn{1}{|c|}{ Dimensión } & \multicolumn{1}{|c|}{ Preguntas por responder } & \multicolumn{1}{c|}{ Indicadores } \\
\hline $\begin{array}{l}\text { Contenido de las } \\
\text { políticas económicas } \\
\text { y sociales que el líder } \\
\text { implementa o preten- } \\
\text { de llevar a cabo }\end{array}$ & $\begin{array}{l}\text { ¿Qué tipo de políticas económicas y sociales } \\
\text { impulsa? } \\
\text { ¿Puede decirse que redistribuye la riqueza? } \\
\text { Si lo hace, ¿cómo lo hace? }\end{array}$ & $\begin{array}{l}\text { Tipo de políticas económicas: nacionalis- } \\
\text { tas, proteccionistas frente a aperturistas y } \\
\text { liberales. }\end{array}$ \\
\hline $\begin{array}{l}\text { Modo en que se da } \\
\text { la salida del líder del } \\
\text { cargo político }\end{array}$ & $\begin{array}{l}\text { ¿Cómo termina su mandato? ¿Hay continui- } \\
\text { dad en sus políticas o desaparecen con el } \\
\text { líder populista? }\end{array}$ & $\begin{array}{l}\text { Reelección inmediata. } \\
\text { Golpe de Estado (militar/cívico). } \\
\text { Juicio político (Congreso). } \\
\text { Termina su mandato y se da una salida natu- } \\
\text { ral del poder. } \\
\text { Autogolpe. } \\
\text { Renuncia. } \\
\text { Autoexilio. } \\
\text { Muerte. }\end{array}$ \\
\hline
\end{tabular}

Fuente: elaboración propia.

DATOS

\section{Los populistas clásicos: José María Velasco Ibarra, el monarca andino}

\section{Contexto}

José María Velasco Ibarra, el Gran Ausente, fue la primera manifestación populista de Ecuador y uno de los fenómenos políticos claves de la política ecuatoriana desde la década de los treinta hasta inicios de los setenta. Como en otros países, la política del régimen oligárquico estaba en crisis y había clases sociales disponibles, que exigían su inclusión en el sistema político. La crisis del cacao, el surgimiento de otros productos de exportación (café, sombreros de paja toquilla, tagua, arroz y petróleo) y un modesto proceso de sustitución de importaciones en el área textil y alimentaria introdujeron modificaciones en el ámbito económico.
Los cambios en la estructura demográfica a raíz del acelerado proceso de urbanización de Quito y Guayaquil, del efecto migratorio y la disminución de la mortalidad infantil, llevaron a que se constituyera un importante sector marginal que se instaló en la periferia de las grandes ciudades, tras la crisis del sistema de dominación liberal (1895 y 1925), así como también supuso la organización de las clases populares, las clases medias y la estructuración de dos federaciones nacionales de trabajadores (De la Torre, 1998, p. 135).

El origen del velasquismo radica en la Compactación Obrera Nacional (1932) aglutinada para apoyar la candidatura presidencial de Neptalí Bonifaz e integrada por hombres de modesta condición social (artesanos, obreros, pequeños comerciantes), afectados por la crisis económica del país causada por la caída de las exportaciones. Tras las elecciones, declaradas fraudulentas por el Congreso Nacional debido al triunfo de las masas populares, este sector respaldó a Velasco Ibarra, que primero 
como diputado y luego como presidente de la Cámara, luchó por la libertad de sufragio y contra el fraude electoral, convirtiéndose en el opositor implacable del presidente de la República en 1934, luego de recorrer el país haciendo contacto personal con la multitud a la que promete: "... liquidar los privilegios, triturar la plutocracia y pulverizar las trincas" (Hurtado, 1999, p. 221).

Velasco Ibarra emergió en ese contexto para reivindicar y guiar a esos sectores disponibles en su camino hacia la política. Fue el que introdujo la política de masas en el país, incorporando a la práctica política (tanto de manera simbólica como en términos concretos) a sectores que se habían mantenido excluidos hasta ese momento de la comunidad política (De la Torre, 1999, p. 302). La naturaleza de su liderazgo contó con algunos elementos comunes a los otros populismos clásicos, ya que en el país andino no se dieron procesos significativos de sustitución de importaciones (Burbano de Lara, 1998), etapas de desarrollo industrial o la emergencia de una burguesía extensa.

En 1934, Velasco Ibarra fue elegido por primera vez presidente de la República con el apoyo del Partido Conservador, tras la renuncia de Juan de Dios Martínez Mera, quien había sido elegido de forma fraudulenta. Durante cuatro décadas, y en cinco oportuni- dades diferentes, condujo el Ejecutivo (19341935,1944-1947,1952-1956, 1960-1961 y 1968-1972) pero no consiguió construir un Estado nacional popular ni traducir sus ideas en políticas estatales sólidas, toda vez que de los veinte años que le correspondía gobernar, solo ejerció once, debido a los constantes derrocamientos que sufrió a través de golpes de Estado, fraude electoral o insurrecciones militares, y solo pudo finalizar uno de sus periodos constitucionales (1952-1956).

Este movimiento político, que no se convirtió en partido político hasta 1968 , cuando se transformó en la Federación Nacional Velasquista para poder competir electoralmente, rigió la vida de país desde 1933, toda vez que Velasco Ibarra contaba con un significativo apoyo electoral, interpretando y recogiendo las demandas de los ciudadanos marginados, principalmente de la costa. De este modo, los principales bastiones electorales del velasquismo se encontraron en esa región.

Si bien para 1944, Velasco Ibarra ya había desempeñado un primer Gobierno (19341935), no es hasta el segundo en el que pone en práctica su estilo populista, en el marco de una profunda crisis económica que hizo que cambiara la estructura social del país a raíz de la fuerte movilización migratoria del campo a la ciudad ${ }^{4}$, en momentos de profunda inestabilidad política tras la crisis del sistema liberal

4 Las transformaciones en la estructura social y demográfica del país crearon una nueva relación entre las regiones de la sierra y la costa, y generaron alteraciones en el equilibrio político entre ambas regiones. Si para inicios del siglo xx la costa albergaba al $20 \%$ de la población del país, en la década de los cincuenta pasó al $40 \%$. Guayaquil creció a un ritmo importante: entre 1929 y 1934, al 5,33\% anual y entre 1934 y 1946 siguió aumentando al 2,5\% anual (Cueva, 1998). 
que había regido en el país entre 1895 y 1925. Los cambios en la estructura social del país a raíz del acelerado proceso de urbanización llevaron a que se constituyera un importante sector marginal que se instaló predominantemente en la periferia de las grandes ciudades y pasó a conformar lo que Cueva (1998) denominó como "subproletariado"s.

La última presidencia se inició con el triunfo electoral de 1968, cuando ganó por un estrecho margen, con el $32,85 \%$ de los votos, tras una campaña tranquila, mesurada y sin discursos estridentes para no movilizar a los diversos sectores de la derecha en su contra (Mejía Acosta, 2002, p. 39). Su Gobierno finalizó tras un golpe de Estado realizado por las Fuerzas Armadas como institución

\section{Estilo de liderazgo}

Velasco Ibarra fue el primero en llevar la política a la plaza pública y recorrer el país con un discurso de incorporación política, basado en la honestidad del sufragio. Su estilo se caracterizó por la movilización directa, la política masiva, las relación con la muchedumbre y la identificación con una retórica moralista y maniquea, que estaba por encima del respeto a las instituciones políticas representativas. Velasco Ibarra se convirtió en el elemento aglutinante de sectores desmovilizados, en el eje de diferenciación y polarización de la política ecuatoriana, en el redentor del país, en la personificación del ideal democrático así como también en la fuente de todos los males.

A pesar de los esfuerzos por la inclusión social y política, se hizo muy poco por construir un Estado de derecho en el que los ciudadanos fueran iguales entre sí en materia legal, y gozaran de las mismas obligaciones y derechos (De la Torre, 1998). Su relación con las instituciones democráticas no fue siempre de sujeción y respeto. Abolió las Constituciones de 1935, 1946 y 1970, seńalando que limitaban la voluntad popular que él creía representar y denostaba cualquier intento de organización partidista. Si bien para 1944 el "loco" o "profeta" ya había desempeńado un primer gobierno (1934-1935), no fue hasta el segundo en el que puso claramente en práctica su estilo populista, en el marco de una profunda crisis económica que hizo que cambiara la estructura social del país.

\section{Base social de apoyo y tipo de movilización}

La base social de apoyo fue heterogénea, diversa y multiclasista (Sosa, 2006, p. 41), variando en cada una de sus candidaturas. En la década de los treinta recibió el respaldo del Partido Conservador y, desde ese momento, fue organizando su grupo de "bonifacistas, es decir, liberales de la Sierra que lo respaldaban y algunos sectores de caciques y de terratenientes costeños que también lo hacían" (Ayala, 2006, p. 48). Su base social eran en ese momento las

5 Hurtado (1999) los denomina como marginados, esto es, personas si empleo estable, vendedores ambulantes, artesanos, empleados de la construcción, entre otros, todos ellos dedicados a actividades de baja productividad económica. 
"clientelas artesanales del Partido Conservador y el mundo rural" (p. 48).

En la década de los cuarenta, la base social fue más de corte urbano, con el apoyo de la cúpula de los "compactados" que deciden que Velasco sea presidente, tras la Revolución Gloriosa de 1944. Cuando gana las elecciones en la década de los cincuenta, su base ya era propia (se enfrenta al Partido Conservador) y cuenta con apoyo urbano y costeño, más el movimiento falangista, el Movimiento Social Cristiano y la Derecha. En 1968, la última elección en la que consigue alcanzar la Presidencia, su base electoral se encuentra concentrada solo en tres provincias de la costa e incluso pierde en su provincia de origen, Pichincha.

Esto significa que la composición de clase de sus gobiernos no fue siempre la misma en cuanto al peso relativo que la burguesía, el proletariado, la clase media, los caciques rurales y los militares tenían sobre ellos. Aun cuando esos grupos estuvieron presentes, no contaban con la misma capacidad de influencia ni sus acciones tuvieron las mismas consecuencias.

Con el velasquismo, comienza la participación activa de las masas, los grandes sectores populares, en la política ecuatoriana. Se da la incorporación de sectores que estaban excluidos. Si bien no fueron todos, el velasquismo expandió el electorado del 3,1\% en 1933 al $16,83 \%$ en 1968 . Aún así, la mayoría de la población continuaba excluida del sufragio, por no cumplir con el requisito que exigía la ley respecto a la necesidad de ser alfabeto para el voto (De la Torre, 1998, p. 135) ${ }^{6}$. En cualquier caso, esa expansión de los derechos políticos y sociales tuvo un importante impacto en los sectores más desprotegidos y abandonados del país (fundamentalmente de la costa), lo que supuso una importante democratización del sistema político.

Un grupo social que estuvo bastante distanciado de Velasco Ibarra, sobre todo a partir de las dos últimas administraciones, fue el de los estudiantes. En la tercera presidencia hubo huelgas y el asesinato de un estudiante, Isidro Guerrero. En la década de los sesenta, el enfrentamiento con los estudiantes llegó a su máxima expresión. El movimiento estudiantil ya estaba organizado y muy influenciado por los partidos de izquierda, la Revolución cubana y la tendencia maoísta (Corral et al., 2006).

Junto al fuerte vínculo afectivo generado por las cualidades carismáticas y extraordinarias del liderazgo velasquista, diversos estudios como el de Menéndez Carrión (1986, p. 433) han mostrado cómo el apoyo electoral dado en Guayaquil y las barriadas lindantes estuvo ligado a la presencia de redes clientelares locales, que contribuyeron a la movilización y el reclutamiento electoral en las elecciones de 1952, 1960 y 1968.

Estos seguidores, que veían en Velasco a un líder superior, no eran masas "flotantes", seducidas exclusivamente por los poderes ca-

6 Esto ha conducido a algunos autores como Quintero (1978), a negar la naturaleza populista del velasquismo, y, a otros sectores, a destacar que el velasquismo no era un fenómeno meramente electoral sino que tenía una naturaleza mucho más amplia. 
rismáticos o por su modo de hablar "bonito", sino que además el electorado suburbano se movía de manera pragmática, racional, a través de intermediarios locales que tenían con ellos una relación clientelar. La simbiosis entre movimiento y líder se basaba en la fidelidad de los seguidores y en la exigencia de la más absoluta lealtad por parte de este con respecto a aquellos, lo que ha conducido al fracaso a cualquier intento de continuación del movimiento sin el propio líder ${ }^{7}$.

\section{Estrategias discursivas}

Velasco Ibarra definió al velasquismo de manera ecléctica, centrada en el movimiento y como una doctrina liberal, cristiana y socialista. Su fuerte sentido reformista y nacionalista buscaba representar a las posiciones de los sectores urbanos, trabajadores manuales y migrantes internos. El centro de su discurso era el pueblo, a quien equiparaba con la nación, pero esto no impedía que el contenido del mismo fuera racista, personalista y paternalista. Los slogans de campaña hacían hincapié en el carácter redentor de Velasco y en el modo en que él podía resolver todos los problemas del país ("Con Velasco churrasco, Con Velasco azúcar, con Velasco Todo") (De la Torre, 1999, p. 316).

Si bien su discurso era de carácter inclusivo, debido a que su mensaje se basaba en la incorporación de todos los sectores a la política a través de elecciones, estas intenciones no llegaron a plasmarse en políticas estables que hicieran que el mensaje dejara de ser tal $\mathrm{y}$ transformara a los sectores marginados, que constituían su base social, en ciudadanos de pleno derecho. Precisamente esto es lo que muestra el carácter más simbólico, expresivo, discursivo que institucional y estatal del caso ecuatoriano.

A diferencia de otros populismos clásicos, no articuló a los grupos organizados, no permitió la constitución de un régimen de partidos (por el contrario, lo combatió), y no favoreció la inclusión social a través de políticas universalistas estatales de provisión de bienes públicos. Su principal activo era la ausencia de una organización institucionalizada, ideológicamente coherente, que limitara su pragmatismo en la definición de los contenidos programáticos. El empleo de una laxa "red de amigos políticos" le permitía contar con una amplia base de apoyo y lo presentaba como el "patrón" de una larga lista de grupos diversos (Menéndez, 1986, p. 435).

... no han podido perdonarme que yo triunfe sin partido, que yo triunfe sin pedir a nadie plata ni nada, no me han podido perdonar. Entonces: demagogo. Demagogo porque le he hablado a la multitud y le he dicho la verdad, demagogo porque le he dicho al pueblo que el pueblo tiene derecho a ser libre, a

\footnotetext{
7 "Como dentro de él la fidelidad personal vale más que la adhesión institucional y la disciplina partidaria, aquella ha sido un requisito indispensable para ingresar al grupo de los colaboradores del Dr. Velasco y los que han perdido su confianza han caído en desgracia siendo excluidos del círculo de fieles y privados de toda ascendencia política" (Hurtado, 1999, p. 222).
} 
buscar la justicia, a manejar el Gobierno con su voto, demagogo porque he dicho que el pueblo debe tener carreteras. Todo esto halaga al pueblo y el pueblo ha estado conmigo. Pero no es ser demagogo. Demagogo es engañar al pueblo. ¡Yo jamás he engañado al pueblo! (Declaraciones de Velasco Ibarra en entrevista con Pablo Cuvi, 1975).

El discurso, destinado a amplios sectores, se caracterizaba por la "coexistencia de lenguajes de reforma moral y de clase, que coincidían en su énfasis sobre el personalismo y la inclusión política” (De la Torre, 1999, p. 316). El constante maniqueísmo entre pueblo y oligarquía, como una lucha moral entre el bien y el mal, que luego sería retomado por múltiples líderes populistas ecuatorianos (de izquierda y de derecha), se hizo presente en el discurso interpelativo velasquista, con la propia ambigüedad y escasa precisión empírica de ambos conceptos.

Velasco hablaba como un "profeta, se consideraba la encarnación del pueblo, más allá de las ideologías políticas, los partidos y los programas de gobierno. Su falta de respeto y de fe en cualquier partido político u ideología, y su fe en el pueblo como única organización política provocó fisuras en las alianzas" que le sostenían (De la Torre, 1999, p. 325).

... Pueblo heroico al que yo amo y con el cual me siento ligado, después de soportar cuatro años de las más innobles tiranías, y el espanto en el alma nacional destruisteis al pesquisa, lo que nos permite hablar en este instante, conquistasteis el poder para los ciudadanos arrebatándolo a la policía que mantenía el poder absoluto en la persona de un déspota que fomentó la dispo- sición arbitraria del territorio nacional y de sus rentas, el despilfarro de los fondos públicos, la corrupción de municipios, del Poder Judicial y de toda la nación [...] la fuerza del ideal es más grande que las fuerzas de los imbéciles; y que la fuerza salvaje, por aparentemente voluminosa que sea, es incapaz y tiene que ser aprisionada y quemada y destruida cuando se encuentra con las llamas de las balas guayaquileńas y el ejército que se contagia de la emotividad guayaquileńa [...] vosotros que habéis sufrido tanto en los momentos de espera y que estáis ahora aquí congregados, permitidme... Esta es, guayaquileños, toda una revolución; pero es una revolución trascendental, es una revolución profunda, es una revolución orientada y verdadera porque esta es toda la revolución [...] se sintetiza en algo que es como una sola gente honrada y que solamente pueden rechazar los esclavos o los viles: el régimen de la autonomía popular, el sufragio de los pueblos por su propio querer colectivo (Discurso de Velasco Ibarra el 4 de junio de 1944 en Guayaquil, tras la Revolución de Mayo).

Apelando más a la retórica, al discurso, a la belleza del lenguaje sencillo, el líder se comunicaba de manera visual y oral con los sectores marginados: la comunicación radial, la manifestación pública, la reunión barrial, la concentración popular y de las audiencias eran los modos de estar cerca del "hombre" que, en cualquier caso, siempre mantenía las distancias, lo que favorecía la construcción del mito por parte de los sectores marginados. Hurtado seńala que el subproletariado tiene una cultura oral y visual, siendo la oratoria lo que facilita la comunicación entre líder-seguidor antes que la palabra escrita o el pensamiento razonado. En este sentido, las palabras valen más por su expresión formal que por su contenido ya 
que lo que se busca es llegar a los corazones y generar pasiones ${ }^{8}$.

\section{La salida de la Presidencia}

En el último gobierno, antes de ser derrocado por las Fuerzas Armadas, se declaró dictador tras un "autogolpe" realizado el 22 de junio de 1970 con el apoyo unánime de los militares y todos los sectores de la oligarquía. La suspensión de la Constitución y la clausura del Congreso fueron justificados en una profunda crisis política, desatada por el conflicto con el Poder Legislativo, donde una mayoría adversa (solo 4 de los 70 diputados eran velasquistas) aprobó un presupuesto desequilibrado.

El 15 de febrero de 1972, el general Rodríguez Lara, en nombre de las Fuerzas Armadas en su conjunto, le dio un golpe de Estado, lo derrocó y lo exilió en Argentina. Tras su Gobierno comenzó un periodo de dictablanda en el que los militares gobernaron hasta 1977, cuando se comenzaron a dar los pasos para la transición democrática.

La manera de ver y hacer política de Velasco, la transformación moralista del discurso, la lucha personalista y maniquea entre sectores que aparecen como representantes de la bondad y la virtud frente a sus enemigos que encarnan la maldad, ha legado una visión dicotómica y excluyente de la política, que aún se mantiene viva. Si bien los movimien- tos populistas ecuatorianos incorporaron a sectores excluidos a la democracia, su discurso y acción política fue poco institucionalista y escasamente respetuoso de los procedimientos democráticos así como también maniqueos, personalistas y excluyentes.

Este estilo político, que termina siendo tan autoritario como lo que originalmente combate, fue uno de los principales legados del populismo velasquista a la frágil democracia ecuatoriana. La creación de un estilo de movilización política y la inclusión de la retórica como agente de movilización, excluyendo a las instituciones democráticas como parte del juego político, supusieron anclajes que se han mantenido de diversa manera en el desarrollo histórico-político ecuatoriano.

\section{Los neopopulistas neoliberales: Abdalá Bucaram Ortiz, el líder de los pobres}

\section{Contexto}

La elección de 1996 permitió la llegada la poder de esa tendencia a través del Partido Roldosista Ecuatoriano (PRE) y su líder, Abdalá Bucaram Ortiz, cuñado de Jaime Roldós Aguilera, primer presidente de la democracia (1979-1981), quien falleció en un accidente de aviación a medio mandato, y sobrino de uno de los patriarcas populistas de Guayaquil de las décadas de los sesenta y setenta, Assad Bucaram Elhmalín. Bucaram Ortiz ganó con

8 "Cuando la masa se encuentra con un caudillo carismático que reúna estas características se abandona a su posesión. Establece una relación personal caracterizada por la devoción filial, la lealtad a toda prueba y el respaldo incondicional, a cambio de lo cual aspira a recibir toda suerte de beneficios" (Hurtado, 1999, p. 219). 
un amplio margen al candidato del Partido Social Cristiano, Jaime Nebot Saadi, tras dos intentos fallidos en 1988 y en 1992, en la segunda vuelta electoral. La misma confrontó a dos políticos costeños, que si bien eran considerados ambos como populistas, representaban valores, grupos sociales y culturales e intereses económicos diversos, sostenidos sobre aceitadas redes clientelares.

\section{Estilo de liderazgo}

La política roldosista se ha caracterizado por un fuerte personalismo y por la identificación de los seguidores con el poder carismático del líder, expresando una nueva religión secular y proveyendo, al mismo tiempo, un instrumento de control social sobre las masas. Los sectores populares reprodujeron en Bucaram aquello que sońaban ser. Lo que le sucedía a este también le sucedía al pueblo, siendo él la única persona capaz de resolver los problemas de la gente común debido a sus cualidades extraordinarias.

La intención de Bucaram, una y otra vez, ha sido recalcar sus orígenes humildes, su pertenencia a una clase social baja, su esfuerzo por superarse (como hacía discursivamente Fujimori) y su exitoso ascenso social. Su liderazgo fue el principal recurso del constructo originario de la cosmovisión roldosista. $\mathrm{Mu}$ chos activistas del partido se han descrito más como abdalacistas que como roldosistas, y la organización partidista se ha convertido en un instrumento sin autonomía, a disposición de la voluntad de su "director supremo".

El populismo frente al roldosismo:
... Al Partido Roldosista lo han ubicado siempre como un mojón de María, no saben dónde colocarlo y por ello lo han identificado más como un partido populista. El populismo es una doctrina, una historia, todos lo conocemos, donde predomina más la figura regia del hombre, más el carisma de la persona o las ideas totalitarias y demagógicas en reemplazo de las ideas y los planes [...] (Declaraciones de Abdalá Bucaram Ortiz en una entrevista personal con Flavia Freidenberg en Ciudad de Panamá el 16 de agosto de 2000).

Bucaram se ha presentado a sí mismo como un hombre del pueblo, al que glorifica destacando sus cualidades populares en su manera de comer, vestir y de ser, a pesar de vivir en un piso en Panamá valorado en más de un millón de dólares (Freidenberg, 2003). Pero como lo que importa es lo simbólico, los oprimidos y los pobres ven en Abdalá a su genuino representante. El pueblo ha pasado a ser la encarnación de los verdaderos valores morales, mientras que los “otros” (la oligarquía, los socialcristianos o el enemigo de turno) han sido la personificación de la maldad. Las señoras elegantes eran "viejas vagas que nunca han cocinado, ni planchado", y el discurso de Bucaram confrontaba de manera maniquea al "verdadero" Ecuador, el de "los pobres", con el Ecuador de "esa gente", los "vende patrias" (De la Torre, 1998).

Los mitines han sido vistos siempre como encuentros que otorgan dignidad simbólica a quienes participan en ellos, lo que se ha entendido como la democracia del espacio público (De la Torre, 1996; 2009), a través de la cual se pasa a formar parte de un colectivo que presta identidad a los que actúan en él. Los espacios públicos son los escasos momentos 
en los que es posible cuestionar y transgredir el orden social pero sin por ello llegar a una postura radical antisistema. Son el espacio en el que se renueva la relación con los seguidores y se permite reordenar la identidad colectiva. De este modo, los roldosistas han visto a la democracia como "actos de masas donde se aclama a los líderes y se abuchea a los rivales [la oligarquía]" (De la Torre, 1998).

... El pueblo quiere ver a Abdalá, porque para ellos Abdalá es un espectáculo, es un chou (show), yo que sé. Ellos ríen, lloran, sus pasiones las descubren en Abdalá cuando está en una tarima. En estos términos sí creo que soy el grito de agonía, como dicen, del populismo ecuatoriano, pero ahí está Abdalá, ahí está el espectáculo, ahí está lo que quieran, pero ahí está, [...] yo creo ser el pueblo, yo creo ser el indio, el cholo, el negro. Yo los conozco; yo me compenetro con ellos (Declaraciones de Abdalá Bucaram Ortiz durante la campaña electoral de 1988. El País, "Bucaram: soy el grito de agonía del populismo”, Madrid, 8 de febrero de 1988, p. 4).

Las relaciones con el líder han sido identificadas como de suma cero: se está totalmente a favor (y se lo considera como la encarnación de la bondad) o se está totalmente en contra. Es una división en dos de lo social. Bucaram Ortiz interpeló al pueblo en contra de un grupo dominante, que va variando de cara según él lo considere. No es un grupo específico y particular, invariable en el tiempo, sino que, dependiendo del momento en que se apele a este recurso discursivo, puede ser vinculado con actores y grupos diversos.

Las siguientes son las declaraciones de una militante roldosista sobre el estilo de liderazgo de Abdalá:

... Yo a mi partido lo adoro. En las buenas y en las malas. No solamente cuando el partido está arriba. No, en las buenas y en las malas [...] El corazón me pide que yo sea roldosista y seguiré siendo hasta cuando el señor me tenga. ¿Por qué? Porque es un partido que a todo humilde, toditos, toditos, por el trato con el presidente... a todos él nos ha ayudado a trabajar. Nos ha dado trabajo. Por eso es que la gente viene al partido (declaraciones de una jefa de sector del Guasmo Sur en una entrevista realizada por Flavia Freidenberg en Guayaquil, el 8 de septiembre del 2000, en la Sede Nacional del Partido Roldosista Ecuatoriano).

\section{Base social de apoyo y tipo de movilización}

Su base de apoyo social estaba integrada por los sectores más pobres del Guasmo ${ }^{9}$ guayaquileño, de las ciudades medias costeñas y de los sectores migrantes que votan en la sierra pero que trabajan en la costa. También se encontraban los "nuevos ricos", élites emergentes (por ejemplo, comerciantes descendientes de libaneses) que se han enriquecido en negocios no muy claros, incluso, del contrabando. A pesar del dinero que puedan tener esas élites, eso no supone el ingreso a las redes de poder social y político de corte oligárquico existentes en Guayaquil.

9 Barrio de la ciudad de Guayaquil, que se encuentra al sur y en el que viven pobladores en situaciones precarias y marginales. 
Estos empresarios se sienten excluidos del sistema económico y del poder político real, por lo que intentan acceder a él a través de una alianza discursiva con los sectores populares. Además, hay algunos intelectuales exmarxistas que se incorporaron al movimiento y políticos locales que fueron desplazados de la familia socialcristiana y que encontraron en ese momento en los roldosistas un espacio alternativo desde donde disputar el poder político y hacer trabajo social y clientelar.

Declaraciones de Abdalá Bucaram sobre los sectores que representa el PRE:

... [a quién representa el PRE] a los pobres, a los descamisados. Donde hay necesidad, está el Partido Roldosista, donde hay dosis de racismo, combatimos el racismo; vemos al ser humano como un ser humano que tiene que predicar con el sudor de su frente; que comulguen con nosotros aquellos seres que busquen una comunión espiritual entre el pueblo y Jaime Roldós Aguilera. Si ahí están estos grupos clientelares, que no sé cómo les llaman, si ahí está el lumpen, las cocineras, las prostitutas, los marineros, los carpinteros, los albañiles, en buena hora. Si ahí está una clase media liberal, de pensamiento liberal, en buena hora. Si están los profesionales liberales, en buena hora. Yo no me preocupo en realidad quién está en el partido roldosista. Me gustaría que esté Febres Cordero para mejorarlo como persona, para reformarlo, para hacerlo un hombre, ¿¿no?

El PRE básicamente tiene una conformación realmente un poco populista. Porque realmente los Comandos Provinciales no entienden de elecciones internas... se hacen, se hacen pero les importa un carajo. Siempre es el director, el líder de la provincia, el que va disponiendo los nombres, el que tiene mayor peso (Declaraciones de Abdalá Bucaram sobre los sectores que representa el PRE.
Entrevista personal realizada por Flavia Freidenberg en Ciudad de Panamá, el 16 de agosto del 2000.

Para sus seguidores, Bucaram Ortiz era "Dios", "un amigo que sabe escuchar los problemas de uno", "un líder a quien seguir", "un hermano a quien respetar", "el miembro más inteligente de la agrupación", "el presidente de los pobres y los humildes", "el loco que ama”, el "abogado", "alguien que comprende el sufrimiento del pueblo", el "director supremo", el "presidente" o, simplemente, "el líder”. El estilo de movilización, la cultura política y la retórica discursiva creada por los líderes populistas del pasado continúan siendo un patrón de comportamiento de la política ecuatoriana (De la Torre, 1996). Las siguientes son las declaraciones de una militante roldosista sobre el líder:

... Abdalá es una persona muy buena, una persona [de la] que dicen que es guaso, que él es loco. De loco, él no tiene nada. Él tiene el cerebro más bueno que los que dicen que son locos porque si él fuera loco él no cantaría. Él es un gran abogado y los hace pedazos a todos. Y él solo se defiende. Ellos convocan el uno, el otro, para ponerlo por el suelo a él y vea ahorita como está el país. Por cuestiones de ellos que son unos malos dirigentes, son rateros. Ellos roban para ellos, nunca para el pobre. El abogado Abdalá toda una vida él ha abogado para la gente pobre. Y por eso es que él es querido, él es querido. Y si aquí le ganan los votos es porque estos de la 6 [se refiere a la lista del PSc] son los dueños de los tribunales, donde ellos hacen y deshacen. Ellos hacen, nos roban. Ellos hacen y deshacen, ellos [son] dueños de todas las mesas. Dueños de los tribunales. Ellos son los grandes señores (declaraciones de una jefa de sector del Guasmo Sur en una entrevista realizada por Flavia Freidenberg 
en Guayaquil el 8 de septiembre del 2000, en la Sede Nacional del Partido Roldosista Ecuatoriano).

\section{Estrategias discursivas}

El estilo discursivo de Bucaram Ortiz ha manifestado desde sus comienzos algunos rasgos característicos del discurso populista clásico. En sus intervenciones son constantes las apelaciones a la dicotomía pueblo-oligarquía, la construcción de la política como una relación amigo-enemigo, la personalización del mensaje, la lucha contra el orden establecido, la inclusión de propuestas de corte clientelar y la exaltación del líder como un ser superior ${ }^{10}$.

Sus mensajes siempre han usado un lenguaje emotivo, vulgar y popular: apela al amor, con frases mesiánicas y religiosas ("será como una lucha entre diablo e hijo de Cristo"; "Diosito es roldosista y al subir el petróleo ayudó a este Gobierno a pagar la deuda externa”); con un mensaje sencillo, poco complicado, algunas veces en tono amenazante, con cierto corte moralista y transgresor. Desde la primera campaña electoral en 1984, Bucaram Ortiz prometió de todo bajo el lema "no es cosa de locos": programas de trabajo para dar vivienda popular, rellenar el suburbio, pavimentar las áreas marginales, dotarlas de agua potable, mercados, escuelas, lugares de recreación, un Banco de Zapatos y acceso a teléfonos para todo el pueblo.

Sus ofertas siempre fueron efectistas. En 1992 volvió a emplear recursos discursivos que apelaban a la utilidad del voto y a la consideración de beneficios en términos clientelares (como por ejemplo la frase ";qué te han dado los otros políticos?”). El uso del clientelismo como recurso, el hecho de dar "algo" a cambio de un voto, ha sido una de las estrategias fundamentales que han empleado los políticos roldosistas para relacionarse con los sectores populares (Freidenberg, 2003).

El clientelismo, el mesianismo y el partido roldosista según Bucaram:

... un día soñé con la Virgen que me dijo ya eres libre, regresa junto a mi pueblo y sálvalos de la miseria. Te unirás a los perseguidos y firmarás una patria libre, vencerás a un no creyente, porque el mismo diablo lo viste de bueno [...] Yo tengo derecho a ser presidente porque me he preparado, estudiado, pagué la conscripción política, he cometido errores como todo ser humano pero jamás mate a nadie o trafiqué con drogas: nunca he ingerido alcohol ni he fumado cigarrillos por respeto a mis hijos... Voy a moralizar al país para que nunca más haya licitaciones para el bolsillo de los gobernantes (Freidenberg, 2003).

Tú me das tu voto yo te doy una escuela; tú me das tu voto y yo te doy libertad; tú me das tu voto yo te doy salud; tú me das tu voto yo te doy comprensión.

El actual Gobierno les prometió pan, techo y empleo; y yo, como soy del pueblo, les voy a dar jama, caleta y camello (Declaraciones de Bucaram. El País, "Bucaram afirma que la elección presidencial es la lucha entre un hijo de Dios y uno del diablo", Madrid, 7 de mayo de 1988, p. 6).

10 La descripción de los elementos del discurso populista puede encontrarse en Panizza (2001, 2008) o Laclau (2005). 
En sus campańas electorales de 1988, 1992 y 1996 Bucaram usó la televisión para potenciar el antagonismo entre el pueblo, cuya voluntad decía representar, y la oligarquía que debía ser destruida. El pueblo era entendido como la encarnación de la auténtica nación-buena, justa y moral, y definido por lo que no es. Con esta visión dicotómica de la realidad, Bucaram simplificó el escenario político, enseñando a sus seguidores los buenos de los malos.

... La oligarquía es el gobierno de pocos en perjuicio de muchos. Se identifica en los sectores bancarios, en los sectores financieros, en los sectores eclesiásticos, en los sectores políticos. Porque uno de los grandes males del Ecuador es que la oligarquía política es la nueva oligarquía económica del Ecuador. Y obviamente, respetando a la Iglesia y respetando a las Fuerzas Armadas, es indiscutible que ha habido un matrimonio indisoluble en el último siglo entre la oligarquía, las Fuerzas Armadas y la Iglesia. Es una lástima que el empresariado económico del Ecuador pueda estar bajo la tutela de una oligarquía política. Porque no hay nada más hermoso que empresarios independientes, que hagan plata, que trabajen y que entiendan lo que es el capital y el trabajo. Pero cuando hay el monopolio y la concentración de la riqueza y la utilización de las leyes en beneficio de unos pocos y en perjuicio de muchos es donde surgen los Abdalá Bucaram (declaraciones de Abdalá Bucaram a Freidenberg en Ciudad de Panamá, 16 de agosto de 1996).

En las estrategias discursivas también importa el modo en que los otros candidatos han presentado al líder populista. En la mayoría de los casos, la oligarquía ha estado representada en la figura de los patricios guayaquileños y en la élite ecuatoriana, para quienes Bucaram es el "repugnante otro", "la encarnación de la barbarie, la falta de cultura y civilización de los marginales" (De la Torre, 1998). Durante la campańa de 1996, Nebot prometía la civilización y el progreso frente a la "barbarie" de los sectores suburbanos personificados en Bucaram. Esta representación maniquea de la realidad política sintetizó la estrategia socialcristiana de atemorizar al electorado con la amenaza de la "irracionalidad" y el "barbarismo" de los populistas, construyéndolo como el último obstáculo para el progreso y la modernización del Ecuador. Solo con la desaparición de Bucaram y sus seguidores, según los socialcristianos, sería posible el desarrollo del país.

\section{El contenido de las políticas económicas y sociales}

Si bien las apelaciones a la liberación nacional han sido insistentes en el desarrollo político del roldosismo, estando presentes incluso en los Estatutos partidistas y la Declaración de Principios, una vez en el poder esa postura no ha tenido mucho que ver con su programa de gobierno. El Gobierno roldosista intentó implementar políticas de libre mercado, privatización del sector público, convertibilidad de la moneda (contratando al economista argentino Domingo Cavallo), flexibilización laboral, apertura de los sectores energéticos al capital privado, inversión extranjera, transformación del sistema de seguridad social e implementación de una rigurosa política tributaria.

Los empresarios ecuatorianos no confiaron en ese plan de convertibilidad, argu- 
mentando que la situación económica de Argentina era muy distinta a la de Ecuador en ese momento. Su defensa de que era necesario un "verdadero capitalismo para que las empresas compitan entre sí y no se produzcan monopolios ni oligopolios" (El Universo, Guayaquil, 18/06/96) dio cuenta de ello y mostró el sentido neoliberal del discurso roldosista. Es más, una vez en el poder, el frente económico estuvo integrado por los principales empresarios y banqueros (entre ellos Álvaro Noboa), poniendo en marcha políticas aperturistas y de corte neoliberal.

El poco tiempo de su mandato (menos de seis meses) no permitió ver hasta qué punto Bucaram impulsaría realmente las políticas que había prometido en sus discursos, propias del populismo clásico, o seguiría los pasos de presidentes vecinos de hacer en el gobierno todo lo contrario a lo que se había prometido en campańa. Bucaram ejerció el poder en esos meses con un fuerte sentido patrimonialista del cargo, con un conjunto de nombramientos oportunistas, basados en el nepotismo y con un sentido clientelar del Estado.

Los acontecimientos de protesta social y de malestar de la clase política y empresarial del país se sucedieron, y un masivo movimiento ciudadano, principalmente centrado en la ciudad de Quito, llevó al Congreso a tomar un papel de principal actor institucional insólito en la historia ecuatoriana. Al mismo tiempo, las Fuerzas Armadas, en la persona del jefe del Comando Conjunto, un héroe del Cenepa (la guerra contra el Perú), el general Francisco Moncayo, desempeñaron un papel arbitral de primer orden. Bucaram no había conseguido establecer una alianza con los militares y las élites empresariales ni tampoco contaba con un bloque legislativo mayoritario.

La personalidad excéntrica de Bucaram, con su errática actuación, los nombramientos de familiares, los indicios de corrupción que inmediatamente afectaron a su entorno próximo y las incipientes medidas económicas de fuerte contenido neoliberal precipitaron una crisis de una amplitud desconocida al inicio de 1997, que provocó la salida anticipada de Bucaram de la Presidencia.

\section{La salida de la Presidencia}

La crisis del 6 de febrero concluyó con la destitución de Bucaram por incapacidad física y mental, quien se exilió primero en Argentina y luego en Panamá y, tras la pugna entre la vicepresidente Rosalía Arteaga y el presidente del Congreso Nacional, Fabián Alarcón, este finalmente fue elegido presidente interino el 12 de febrero por los dos tercios del Congreso, recibiendo el mandato de abrir un periodo constituyente, eliminar las principales medidas de política económica y poner en marcha una Comisión Anticorrupción.

Un referéndum celebrado el 25 de mayo de 1997 ratificó a Alarcón como presidente interino y abrió la vía hacia la reforma constitucional, aprobándose diferentes líneas de actuación de la nueva Asamblea Constituyente que fue elegida con la participación de todas las fuerzas el 30 de noviembre del mismo año. Bucaram se mantuvo en el exilio hasta enero de 2005, cuando consiguió regresar al país, tras la anulación de los juicios en su contra por delitos de corrupción durante su mandato, por parte de una Corte Suprema de Justicia 
afín a sus intereses, elegida por una mayoría oficialista en diciembre de 2004, integrada por el PRE, el Partido Sociedad Patriótica (PSP) y el Partido Renovador Institucional Acción Nacional (PRIAN), del millonario bananero, Álvaro Noboa.

Su regreso pateó el tablero político, generó una fuerte crisis de gobernabilidad, alta movilización social de rechazo y apresuró la caída del presidente Lucio Gutiérrez del PSP en abril de 2005, bajo la "Revuelta de los forajidos”. Esta nueva crisis institucional provocó la caída de Gutiérrez, su destitución por parte del Congreso por abandono del cargo, nombrando de manera inmediata como sucesor al vicepresidente, el independiente guayaquileño Alfredo Palacio. Esto hizo que Bucaram regresara rápidamente a su exilio panameño. La elección de una nueva Corte Suprema de Justicia eliminó el sobreseimiento de Bucaram, quien continúa procesado por los delitos de peculado y malversación de fondos públicos.

\section{Populismos contemporáneos.}

\section{Álvaro Noboa Pontón: el populismo mesiánico y caritativo}

\section{Estilo de liderazgo}

El PRIAN, bajo la conducción de Álvaro Noboa Pontón, inició su tarea electoral en 2002 con campañas de salud, educación, empleo y la distribución de recursos a través de la fundación Cruzada Nueva Humanidad.
Esta organización realiza trabajo electoral, de corte social, con fondos propios de Noboa. Con este trabajo, el partido y el propio Noboa ocupan el lugar que le corresponde al Estado en la satisfacción de las demandas básicas de los ciudadanos más desprotegidos.

Según su página web $^{11}$, durante 2005, la fundación realizó 270 visitas a la mayoría de las provincias ecuatorianas, atendiendo a 135.000 pacientes. En esta elección ya se presentó como candidato presidencial de su agrupación política, el Partido Renovador Institucional de Acción Nacional (PRIAN), que había sido creado en 2001 como una plataforma para estructurar una base de apoyo nacional que le ayudara en su candidatura. Esta no fue la primera vez que se presentaba como candidato a presidente, ya que lo había intentado en 1998 a través del PRE y tras la caída de Bucaram Ortiz. Noboa había intentado además llegar a la Presidencia en 2002, 2006 y 2009, y en la mayoría de las citas electorales solo consiguió pasar a la segunda vuelta (1998, 2002 y 2006).

Su estilo de liderazgo patrimonialista no lo muestra como un hombre con cualidades excepcionales ni con altas dosis de carisma como un populista clásico. Noboa ha pretendido comprar ese carisma a través de su millonaria "maquinaria política", que da incentivos selectivos materiales (dinero, recursos) a cualquier potencial seguidor, sobre la base del intercambio clientelar, el compadrazgo y el asistencialismo individual.

11 www.alvaronoboa.com 
El carácter antipartidista de Noboa se basa en la ausencia de trayectoria políticoinstitucional y en su condición de antiélite patricia guayaquileña. Su concepción de lo público mezcla la lógica empresarial, con un fuerte clientelismo caritativo y mensajes celestiales, que dan cuenta de un populismo religioso y mesiánico. Por ejemplo, en la presentación de su candidatura en el Auditorio de la Democracia del tSe el 15 de agosto de 2006 dijo: "Como héroe de Dios, con la Biblia en la mano, estoy diciéndoles cobardes los voy a vencer" (El Comercio, Quito, 16/08/2006).

\section{Base social de apoyo y tipo de movilización}

La cholocracia populista, que supone la movilización de los sectores medios y bajos excluidos del país, ha sido una de las más demandadas por los nuevos líderes populistas. Esta cholocracia está integrada por los comerciantes informales, campesinos pobres, subempleados, excluidos e incluso militares que no han conseguido cubrir sus expectativas a través de los mecanismos de movilización de los partidos tradicionales. Bajo el discurso de la revancha y del mesianismo caritativo, estos sectores apoyaron masivamente al PRIAN y también al Partido Sociedad Patriótica de Lucio Gutiérrez.

Noboa y, el hermano de Lucio, Gilmar Gutiérrez, siguiendo el discurso populista clásico, estructuraron sus organizaciones, fortalecieron la relación con dirigentes de base y "robaron" la lealtad de los intermediarios locales al PRE y al PSC en los sectores más pobres y menos educados de la población (PRIAN), o fracturaron al movimiento indígena bajo la premisa del clientelismo y el patronazgo (PSP).

El trabajo electoral de Noboa en 2006 combinó cierta "americanización” en el estilo y en las herramientas usadas para movilizar el voto con una agresiva campańa clientelar. El candidato entregó microcréditos personales (de 1000 dólares), ordenadores, materiales para la construcción, camisetas y comida (banano, arroz, fideos, conservas) a pobladores de los sectores populares o trabajadores de sus empresas (El Café, Chocolates Noboa, Interamericana de Tejidos o Banco del Litoral) y sillas de ruedas (una por local que se visitaba).

Si bien estas estrategias no han sido nuevas en la política ecuatoriana, ya que el trabajo electoral barrial está ligado a los intermediarios que movilizan a los potenciales electores, conocen sus demandas, distribuyen los recursos clientelares e incluso proveen de protección a los candidatos en sus incursiones a los barrios, en esta oportunidad se dio la "mediatización del clientelismo". Fue común ver en la televisión el modo en que el candidato daba recursos materiales a los que se movilizaban en su apoyo (sillas de ruedas, materiales de la construcción, fundas de comida, entre otros).

El éxito del PRIAN en el conurbano guayaquileño, los distritos de mayor concentración de electores económicamente marginados, dio cuenta del nivel de penetración que tuvo la estrategia clientelar prianista y alertó sobre la posible transferencia de dirigentes barriales de los partidos tradicionales hacia el PRIAN. El tipo de campaña puerta a puerta y con caravanas motorizadas que desarrolló Noboa puso en evidencia el apoyo socialcristiano y 
roldosista a esta candidatura, y el traspaso de los dirigentes barriales en busca de recursos para distribuir.

El candidato jugó al fútbol y al voleibol con los vecinos de los barrios, hizo caminatas puerta a puerta junto a Gabriela Pazmiño y Carlos Víctor Morales (candidatos del PRE), con Guillermo Pichi Castro (presidente de la Corte de Justicia de facto instaurada durante el gobierno de Lucio Gutiérrez) o con Pascual del Cioppo (presidente del PsC) y Clemente Vázquez (dirigente socialcristiano en Manabí). Además, hizo promesas de agua potable y calles pavimentadas, visitó escuelas y se reunió con sectores marginados en los barrios más populares de Guayaquil (Febres Cordero, Isla Trinitaria, Nueva Prosperita, Flor de Bastión o Lomas de la Florida, entre otros), donde resulta muy difícil ingresar sin una buena red de intermediarios barriales.

... Los envidiosos no quieren que regale sillas de rueda a los pobres, que no dé de comer, que no dé medicinas a los ecuatorianos. ¿Qué quieren? Ellos lo único que quieren es darle bala y palos.

Mi misión es sacarlos de la pobreza y convertirlos en personas de clase media que tengan vivienda, educación, empleo y salud como la tienen en Espańa, Estados Unidos, Chile e Italia (Declaraciones de Noboa frente a las críticas de sus ofertas de ayuda a las víctimas de la erupción del volcán Tungurahua. El Comercio, 23 de agosto y 13 de noviembre de 2006).

\section{Estrategias discursivas}

El discurso autoritario, mesiánico y despectivo de Noboa contra sus adversarios po- líticos fue una constante. En su intento por ganar la elección trató de asustar a los votantes asegurando que su rival iba a ser un títere de Chávez, lo calificó de "peligro comunista" y de "terrorista", intentando que el presidente venezolano se introdujera en la campaña electoral y esto polarizara al electorado, como había ocurrido antes con la elección de Ollanta Humala y Alan García en Perú. Señaló además que intensificaría las relaciones con Estados Unidos y Colombia y, por el contrario, no tendría relaciones con Hugo Chávez ni con la Cuba de Fidel Castro.

El dueño de más de cien compañías, con amigos cercanos en Washington y una fuerte base dentro de la comunidad empresarial de la ciudad costera de Guayaquil, recorrió el país como mensajero de Dios, como un salvador, prometiendo la creación de empleos, la construcción de casas y el incremento de los salarios. Con propuestas concretas enfrentaba a los mensajes y ofertas abstractas de los otros candidatos. Por ello, reeditó el famoso "pan, techo y empleo", como una manera de atraer a un electorado pobre, que alcanzaba al $60 \%$ de la población. Se mostró incluso mucho más asequible que en campañas anteriores con el mismo discurso religioso: "como Cristo, todo lo que quiero es servir... para que los pobres puedan tener casa, asistencia social, salud, educación, empleos", así como también con el uso de la Biblia y su constante convocatoria a orar en los mitines.

Tres elementos diferencian la manera en que el PRIAn hizo esta vez campańa electoral en relación con las anteriores (Recalde, 2007, p. 24): a) la aceptación de participar en debates con otros candidatos (como en el organizado 
por la CNN durante la primera vuelta); b) la participación en pseudos-acontecimientos en TV (entrevistas) durante la segunda vuelta con la intención de discutir sus propuestas y atacar a Correa, y c) su intención de formar alianzas de cara a la segunda vuelta, a diferencia del proceso de 2002 donde rechazó contar con el apoyo de otros partidos (Quintero, 2005, p. 24).

\section{Rafael Correa Delgado: la revolución ciudadana}

\section{Estilo de liderazgo}

El estilo de liderazgo de Rafael Correa se articuló en el enfrentamiento directo con la clase política y en las posturas del movimiento forajido de abril de 2005. El economista había sido uno de los activos propulsores de las protestas de ese movimiento contra Lucio Gutiérrez, lo que lo llevó a ocupar el cargo de ministro de Economía del Gobierno de Alfredo Palacio durante cuatro meses. Radio La Luna, que se convirtió en la "vocera de los forajidos", concedió amplios espacios a Correa, quien criticó la política económica de Gutiérrez y se pronunció por su destitución. Cuando llegó el momento, Correa, desde la radio, convocó a la primera manifestación de los forajidos, tras el fracaso de la movilización de los municipios y consejos provinciales.

En las noches siguientes, los forajidos se autoconvocaron con el "cacerolazo" y el "correazo" en la Tribuna de Los Shyris, lugar que pasó a convertirse en la principal central de campaña del candidato. A pesar de que el movimiento forajido rechazó que cualquier persona los utilizara como trampolín político, lo cierto es que Correa consiguió mayor visibilidad tras esa movilización y acceder al cargo ministerial desde donde lanzó durante 100 días cruentos ataques contra los acreedores de la deuda externa, los entes internacionales de crédito, el contrato con la empresa petrolera oxy, la firma del TLC así como también procuró tender puentes económicos y políticos con el gobierno de Chávez.

$\mathrm{El}$ "que se vayan todos" fue entonces un pilar importante del discurso de campaña y propuesta del plan de gobierno de Correa y Lenin Moreno, su candidato a vicepresidente, y del movimiento independiente que articularon bajo el nombre de Alianza Patria Altiva y Soberana (PAIS). Esta Alianza estaba integrada por diversos movimientos y grupos sociales como Iniciativa Ciudadana, Acción Democrática Nacional, Jubileo 2002 y Movimiento Alfarista Bolivariano, intelectuales de izquierda y dirigentes de movimientos de derechos humanos.

Este docente universitario, con estudios de posgrado en Estados Unidos y Bélgica, que ha sido consultor del Banco Interamericano de Desarrollo (BID), buscó articular su ambiciosa "revolución ciudadana" bajo la protección del boliviarianismo chavista, su soberanía ideológica, cercana a la doctrina social de la Iglesia, y su posición de outsider radical. Su candidatura supuso la postulación de una persona sin pasado, sin partido, sin experiencia política previa sobre la cual comparar, que encarnó el cambio frente al inmovilismo. Su estrategia de no presentar listas de diputados lo colocó en un margen diferente a los "mismos de siempre", aun cuando algunos de los dirigentes que lo 
acompańaron en la campańa y que luego han asumido puestos en su Gobierno cuenten con sendas trayectorias políticas.

\section{Base social de apoyo y tipo de movilización}

Si bien es pronto para señalar claramente la base de movilización social de Alianza PAIs y del propio Correa, lo cierto es que aún durante los primeros meses de gobierno, el movimiento forajido continuaba siendo parte de su sustento social. Desde el gobierno, Alianza PAIs comenzó a articular redes de movilización con el fin de no depender de otros grupos sociales. En este sentido, se fueron creando comités familiares: cada uno con 10 miembros, con la idea de conseguir organizar 50.000 comités en el país durante el año 2007, emulando a los círculos bolivarianos que Chávez organizó en Venezuela.

Según Correa, la crisis política se caracterizaba por lo siguiente:

Y porque los ciudadanos y las ciudadanas del Ecuador ya no soportan más esta situación, porque el país no es capaz de resistir más, hay que hacer una revolución ciudadana, hecha por y para los ecuatorianos. Solo la asamblea constituyente devolverá la dignidad al Ecuador y entregará como siempre le correspondió, el poder a las manos del pueblo [...] Pero esa revolución depende de la fortaleza y voluntad real de cambiar el país en que vivimos y para ello necesitamos el apoyo de todos y todas (Diario Hoy, Quito, 13/11/2006).

\section{Estrategias discursivas}

Durante la primera vuelta, Correa basó su discurso en la propuesta antisistema, que incluyó amenazas de una "revolución ciudadana", la convocatoria a una Asamblea Constituyente soberana que hiciera la reforma política y desconociera a los legisladores recién elegidos en el trámite de convocatoria, y un fuerte discurso antipartidista, basado en la idea de eliminar la corrupción a golpe de "correazos". Su propuesta fue articulada en torno a dos elementos clave: a) la configuración de los partidos como su "otro" antagónico, y b) la propuesta de una reforma política a través de la Asamblea Constituyente.

El equipo de campaña consiguió un “acertado manejo publicitario (coherente, atractivo y con buen uso de elementos de marketing para generar recordación)" (Recalde, 2007, p. 21), y tuvo capacidad para establecer temas a partir de los cuales los demás candidatos tuvieron que posicionarse.

En varias declaraciones del candidato Correa durante la campańa electoral, se pone de manifiesto esta tensión:

¿Quién dijo que la Asamblea debe pasar por el Congreso? El artículo 10, numeral 2, de la Constitución da atribución al presidente para consultar al pueblo sobre asuntos de trascendentales, sin pedir permiso a nadie. El TSE debe convocar y cumplir la orden del presidente. Si no lo hace, tendríamos una dictadura de partidos.

¿Dónde está el problema? Por ejemplo, para renegociar la deuda, ¿̨para qué se necesita al Congreso? Los dueños de la democracia no son 100 congresistas, sino $13 \mathrm{mi}-$ llones de ecuatorianos y ecuatorianas. Es hora de dejar de tener tanto miedo al Congreso y tener más confianza en nosotros mismos. Esta democracia es nuestra ( $E l$ Comercio, 27/11/2006). 
Para la segunda vuelta, moderó su discurso, introdujo un mensaje más emocional y afectivo, buscó mostrarse como un ciudadano más de clase media. Correa y su grupo de asesores se dieron cuenta que era necesario aterrizar las ofertas de campaña ya que mientras Noboa ofrecía cuestiones concretas (vivienda y empleo), él hablaba de valores y reforma política. En este sentido, se reforzó la propuesta de vivienda (con el Bono PAIs); se insistió en el mantenimiento de la dolarización sin dejar de señalar sus críticas (Noboa había dejado saber que iba a abandonarla); se incluyó a la familia en los spots y en los actos de campańa como una manera de dulcificar la imagen del candidato, y se dejó ver en la iglesia como un católico practicante (para contrarrestar la imagen de comunista de la que lo había tildado Noboa).

El partido desarrolló una fuerte campaña negativa con la intención de potenciar los elementos menos favorables de Noboa (que no pagaba impuestos, que explotaba a los trabajadores, que "le gusta más la plata que la patria”, que contrataba a niños para sus empresas, que pagaba salarios injustos, entre otros), moderó su lenguaje (abandonando el cinturón que generaba connotaciones machistas y violentas) y contrarrestó el contenido de las ofertas de la campańa: si Noboa ofrecía dar 300.000 viviendas, Correa impulsó su plan "Socio País" (un programa de medidas para solucionar el problema habitacional, duplicando el bono de la vivienda), el Bono del Desarrollo Humano, entre otras.

Una vez en la Presidencia, continuó con su discurso moralista, maniqueo, centrado en el papel del pueblo como agente del cambio social (denominado en sus apelaciones como ciudadanos) frente a la oligarquía corrupta, que reivindica la meritocracia y los títulos universitarios como requisito de idoneidad y capacidad moral. También retoma el legado de la movilización indígena, apropiándose de los contenidos de sus demandas y articulándolas como parte de su base social de apoyo.

Veamos, por ejemplo, las declaraciones de Correa en el nombramiento de un joven colaborador al frente de la CAE:

Escúchenme corruptos de las aduanas del Ecuador, se acabó la impunidad. Vamos a arriesgar la vida para evitar que se lleven un centavo más de las arcas del sector público" [...] "Santiago tienes todo el apoyo del Gobierno nacional y seguro de los miembros del Directorio. Los buitres rondarán, tratarán de abusar de tu juventud...Confiamos en los jóvenes con tu capacidad, con tu currículo brillante, para que hagas patria aquí en la CAE, moralizándola (El Comercio, Quito, 9 de febrero de 2007).

Además, siguiendo a Chávez, integró a su discurso la idea del socialismo del siglo XXI frente a la política neoliberal. Según el propio Correa, este modelo "está llegando a su fin [...] el nuevo día ha comenzado, de patrias más justas, soberanas y dignas" (El Mercurio, Cuenca, 15/01/2007). Bajo estos principios, prometió la revolución socialista, renegociar la deuda externa, fortalecer la Comunidad Andina de Naciones, rechazar la presencia norteamericana en la Base de Manta y la firma del Tratado de Libre Comercio (TLC), como base de sus políticas antiimperialistas, lo que dio cuenta de las coincidencias ideológicas con Chávez y Morales. 
... Será el gobierno de los indígenas. Como un milagro se han derrumbado los gobiernos serviles, las democracias de plastilina, el modelo neoliberal [...] Ha empezado a surgir esa América Latina altiva, digna, soberana, justa y socialista del siglo xxI [...] América Latina seguirá cambiando, porque lo que vivimos no es una época de cambios, es un cambio de época [...] La noche neoliberal está llegando a su fin...

Hugo Chávez es mi amigo y me siento muy orgulloso de su amistad. Con gente de manos limpias, de mentes lúcidas y de corazones patriotas, como Hugo Chávez y otros mandatarios de la región, siempre será mucho más lo que nos una que lo que nos separe. Pero en mi casa no mandan mis amigos. Aquí no va a mandar ni Bush ni Chávez, solo los ecuatorianos (apartes del discurso de Correa cuando recibe el Bastón de Mando indígena en Zumbahua. El País, el 29 de noviembre de 2006).

\section{El contenido de las políticas económicas y sociales}

El triunfo de Alianza PAIs se entendió como la legitimación en las urnas de los temas que defendía en campaña, pero también como resultado del voto útil de una ciudadanía que eligió a Correa para evitar al populismo religioso, autoritario y mesiánico de Noboa. El hecho de que el presidente no contara con ningún diputado de su partido en un Congreso presidido por el PRIAN, da cuenta de un nuevo gobierno de minoría y de los pocos incentivos para la gobernabilidad del sistema político ecuatoriano.

Los primeros actos de gobierno de Correa fueron decretar la convocatoria a una Consulta Popular para que los ciudadanos se pronunciaran sobre la realización de una
Asamblea Constituyente y un fuerte conflicto con las instituciones debido a dicha convocatoria, fundamentalmente con el TSE y con el Congreso. Grupos de Alianza PAIS y del MPD, afines al Gobierno, protagonizaron violentos incidentes al irrumpir, con rotura de ventanales, forcejeos, insultos, puntapiés, en la sala de sesiones del TSE para reclamar a los vocales la aprobación de la Consulta que había remitido el presidente de la república (La Hora, Quito, 25/01/2007).

... Le puedo enumerar los tres primeros pasos que daré: asumiré el mando, convocaré la consulta popular para la Asamblea Constituyente y me rebajaré el salario de presidente de 8.000 dólares a $4.000[\ldots]$

Nadie ha hablado de disolver el Congreso, sino de formar una Asamblea Constituyente. Lo que vamos a hacer es convocar a una consulta popular, en uso de las atribuciones que la Constitución confiere al presidente, para que el pueblo se pronuncie. ¿¿Se puede esperar algo más democrático? No se trata de disolver ni de pedirle permiso al Congreso, sino de acatar la voluntad del pueblo.

La reforma política es prioritaria, porque mientras sigamos con ciertas mafias dominándonos, será muy difícil sacar el país adelante. La reactivación económica es lo segundo, pero está vinculada a la reforma política, porque las mafias están en todos lados y si no las combatimos tampoco habrá crecimiento (Declaraciones de Correa sobre sus primeros actos como presidente. En "Aquí no va mandar ni Bush ni Chávez, solo los ecuatorianos", El País, el 29 de noviembre de 2006).

Después que el TSE dejara la calificación de la consulta en manos del Congreso, la gente se movilizó en contra de este con gritos de 
"no más queso para las ratas del Congreso" y "queremos la Consulta para llamar a la Constituyente", llegando a suspenderse las sesiones y tensionando las relaciones entre el Legislativo y el Ejecutivo. Con esto, Correa se posicionó ante la opinión pública como juez entre el Congreso y el Gobierno, representando al eje del bien frente al eje del mal, encarnado este en el sistema político corrupto y clientelar de élites irresponsables y su comportamiento patrimonial y corrupto.

La Constituyente fue apoyada por la Confederación de Pueblos Kichwas del Ecuador (ECUARUNARI), organizaciones y movi- mientos sociales de todo el país, así como también por los intelectuales, medios de comunicación y sectores sociales próximos al movimiento forajido que había sacado del poder a Gutiérrez en abril de 2005, pero que en estas circunstancias se convertía en un aliado para procurar apoyo legislativo para la Constituyente. Gracias al bloque de Sociedad Patriótica, en febrero de 2007, se consiguió aprobar la convocatoria de una consulta popular con una amplia mayoría de legisladores (51 votos de PSP, PRE, ID, RED, MUPP-NP, PSFA, entre otros) y la ausencia de los partidos de la oposición.

TABLA 2. COMPARACIÓN DE LIDERAZGOS POPULISTAS

\begin{tabular}{|c|c|c|c|c|}
\hline & Velasco Ibarra & Bucaram & Noboa & Correa \\
\hline Origen & $\begin{array}{l}\text { Civil, movimientista } \\
\text { (Frente Velasquista) }\end{array}$ & $\begin{array}{l}\text { Civil, partidista } \\
\text { (PRE) }\end{array}$ & $\begin{array}{l}\text { Civil, partidista } \\
\text { (PRIAN) }\end{array}$ & $\begin{array}{l}\text { Civil } \\
\text { (Movimiento PAIS) }\end{array}$ \\
\hline Periodo de gobierno & $\begin{array}{l}\text { 1934/1935, 1944/1947, } \\
\text { 1952/1956, 1960/1961, } \\
1968 / 1972\end{array}$ & 1996-1997 & - & 2006- \\
\hline $\begin{array}{l}\text { Condiciones en las } \\
\text { que emerge } \\
\text { Sistema de partidos } \\
\text { Crisis de legitimidad } \\
\text { Crisis de goberna- } \\
\text { bilidad }\end{array}$ & $\begin{array}{l}\text { Crisis } 1929 \text { + régimen } \\
\text { oligárquico } \\
\text { Transformaciones so- } \\
\text { ciales y económicas, } \\
\text { migraciones internas }\end{array}$ & $\begin{array}{l}\text { Crisis económica } \\
\text { Desencanto y recha- } \\
\text { zo élites tradicio- } \\
\text { nales } \\
\text { Multipartidista } \\
\text { no } \\
\text { Sí }\end{array}$ & $\begin{array}{l}\text { Crisis económica } \\
\text { Desencanto y recha- } \\
\text { zo élites tradicio- } \\
\text { nales } \\
\text { Multipartidista } \\
\text { Sí } \\
\text { Sí }\end{array}$ & $\begin{array}{l}\text { Crisis económica } \\
\text { Desencanto y rechazo } \\
\text { élites tradicionales } \\
\text { Multipartidista } \\
\text { Sí } \\
\text { Sí }\end{array}$ \\
\hline Estilo de liderazgo & $\begin{array}{l}\text { Carismático } \\
\text { (weberiano) } \\
\text { personalista }\end{array}$ & $\begin{array}{l}\text { Carismático (webe- } \\
\text { riano) } \\
\text { personalista } \\
\text { nepotismo }\end{array}$ & $\begin{array}{l}\text { Carismático de } \\
\text { situación } \\
\text { personalista } \\
\text { nepotismo }\end{array}$ & $\begin{array}{l}\text { Carismático (weberiano) } \\
\text { personalista }\end{array}$ \\
\hline Control partido & Sí & Sí & Sí & $\begin{array}{l}\text { Relación de sumisión de } \\
\text { los diversos movimien- } \\
\text { tos hacia el líder }\end{array}$ \\
\hline $\begin{array}{l}\text { Partido de Gobierno } \\
\text { mayoría Cámaras }\end{array}$ & $\begin{array}{l}\text { Sí (variable según } \\
\text { gobierno) }\end{array}$ & No & - & $\begin{array}{l}\text { No presentó candidatos } \\
\text { a diputados en primer } \\
\text { periodo } \\
\text { Mayoría en la Asamblea }\end{array}$ \\
\hline
\end{tabular}




\begin{tabular}{|c|c|c|c|c|}
\hline & Velasco Ibarra & Bucaram & Noboa & Correa \\
\hline $\begin{array}{l}\text { Disciplina legisla- } \\
\text { dores }\end{array}$ & Alta & Alta & Alta & $\begin{array}{l}\text { No tenía legisladores en } \\
\text { el periodo 2006-2007. } \\
\text { Alta (de los asambleís- } \\
\text { tas hacia el líder del } \\
\text { movimiento) }\end{array}$ \\
\hline $\begin{array}{l}\text { Ubicación ideoló- } \\
\text { gica }\end{array}$ & - & Centro-izquierda & Centro-derecha & Izquierda \\
\hline \multirow[t]{2}{*}{$\begin{array}{l}\text { Base social de apoyo } \\
\text { Clase baja } \\
\text { Clase media } \\
\text { Clase alta } \\
\text { Sector informal } \\
\text { Sector rural } \\
\text { Tipo de moviliza- } \\
\text { ción política }\end{array}$} & $\begin{array}{l}\text { Policlasista } \\
\text { Sí } \\
\text { Sí } \\
\text { Sí (costa) Migrantes } \\
\text { internos } \\
\text { Sí (costa) }\end{array}$ & $\begin{array}{l}\text { Policlasista } \\
\text { Sí } \\
\text { Sí (intelectuales) } \\
\text { Sí (libaneses) } \\
\text { Sí (Costa) } \\
\text { Sí (Costa) }\end{array}$ & $\begin{array}{l}\text { Policlasista } \\
\text { Sí } \\
\text { Sí (Costa }\end{array}$ & $\begin{array}{l}\text { Policlasista } \\
\text { Sí } \\
\text { Sí (intelectuales) } \\
\text { Sí (sierra + costa) } \\
\text { - } \\
\text { - } \\
\text { Sí }\end{array}$ \\
\hline & $\begin{array}{l}\text { Político } \\
\text { Antiestablecimiento } \\
\text { Ataque a las élites } \\
\text { Clientelismo }\end{array}$ & $\begin{array}{l}\text { Político } \\
\text { Antiestablecimiento } \\
\text { Ataque a las élites } \\
\text { Clientelismo }\end{array}$ & $\begin{array}{l}\text { Empresario } \\
\text { Antiestablecimiento } \\
\text { Ataque a las élites } \\
\text { Clientelismo }\end{array}$ & $\begin{array}{l}\text { Académico } \\
\text { Antiestablecimiento } \\
\text { Ataque a las élites } \\
\text { Clientelismo }\end{array}$ \\
\hline $\begin{array}{l}\text { Contenido pro- } \\
\text { puestas }\end{array}$ & & $\begin{array}{l}\text { Liberación Nacio- } \\
\text { nal (en Declaración } \\
\text { Principios) } \\
\text { Neoliberal } \\
\text { Convertibilidad (no } \\
\text { puso en marcha) }\end{array}$ & $\begin{array}{l}\text { Neoliberal } \\
\text { Aperturista }\end{array}$ & $\begin{array}{l}\text { Antineoliberal } \\
\text { Proteccionista } \\
\text { Nacionalista } \\
\text { Socialista }\end{array}$ \\
\hline $\begin{array}{l}\text { Reformas promer- } \\
\text { cado }\end{array}$ & No & $\begin{array}{l}\text { Sí (no llegó a imple- } \\
\text { mentar) }\end{array}$ & Sí & $\begin{array}{l}\text { ¿? Discurso prosobera- } \\
\text { nía estatal }\end{array}$ \\
\hline $\begin{array}{l}\text { Relación con } \\
\text { medios } \\
\text { Alianza estratégica } \\
\text { Tensión-conflicto } \\
\text { Sumisión medios }\end{array}$ & Sí & Sí & Sí & Sí \\
\hline $\begin{array}{l}\text { Relación con las } \\
\text { instituciones demo- } \\
\text { cráticas }\end{array}$ & $\begin{array}{l}\text { Antiinstitucionalista } \\
\text { Irrespeto a las institu- } \\
\text { ciones }\end{array}$ & $\begin{array}{l}\text { Antiinstitucionalista } \\
\text { Irrespeto a las insti- } \\
\text { tuciones }\end{array}$ & Reforma política & $\begin{array}{l}\text { Antiinstitucionalista } \\
\text { Reforma política } \\
\text { Revolución Ciudadana } \\
\text { Asamblea Constitu- } \\
\text { yente }\end{array}$ \\
\hline Salida & $\begin{array}{l}\text { Golpe de Estado + } \\
\text { Autoexilio }\end{array}$ & $\begin{array}{l}\text { Golpe de Estado + } \\
\text { Autoexilio }\end{array}$ & - & - \\
\hline
\end{tabular}

Fuente: elaboración propia. 


\section{CONCLUSIONES: POPULISMO} Y DEMOCRACIA, O ESA RELACIÓN CONFUSA Y CONTRADICTORIA

La relación entre populismo y democracia es tortuosa y contradictoria. Por una parte, se sostiene que el populismo ha atentado contra la democracia mientras que, por otra, se destaca la capacidad de cambio de las reglas y del sistema político en su conjunto que estos liderazgos tienen, ampliando la participación y extendiendo los derechos de los ciudadanos. Hay sectores populares, intelectuales y nuevas élites que perciben que esta manera de hacer política permite la incorporación de la gente común a las instituciones (Aboy Carlés, 2011; Panizza, 2001) y lo consideran como parte constitutiva de la democracia (Worsley, 1970). Al introducir la glorificación del lenguaje común a la comunidad y defender una concepción de democracia mucho más amplia que la liberal (Canovan, 1999, pp. 4-6), los liderazgos populistas profundizan la democracia.

Esta tensión se expresa en la comparación entre líderes populistas de diferentes momentos de la historia (tanto en Ecuador como en otras experiencias latinoamericanas). Las primeras manifestaciones populistas impulsaron la apertura de regímenes oligárquicos que no permitían (o limitaban) la participación de sectores medios y pobres de la sociedad, favoreciendo la rotación de la élite que controlaba el acceso a los cargos de poder y haciendo más plural la representación política. Por ello, se considera al populismo como una fuerza fundamental en la democratización de los países de la región (Freidenberg, 2007), ya que fa- cilitó la incorporación simbólica y efectiva de sectores que se encontraban excluidos tanto política, simbólica como económicamente del sistema político.

$\mathrm{Al}$ mismo tiempo, muchas de las prácticas políticas usadas por sus líderes eran antidemocráticas e, incluso, excluyentes con individuos o grupos sociales que manifestaban sus críticas hacia ese liderazgo o hacia decisiones y políticas que ese liderazgo promocionaba. Se les integró no como individuos sino como pueblo, transformando los derechos individuales en derechos de un colectivo; potenciando sus formas moralistas, personalistas y autoritarias; favoreciendo la confrontación discursiva y antagónica entre los grupos sociales y exaltando las bondades de la democracia plebiscitaria. Mientras se incorporaba a los individuos como pueblo, se les quitaba su condición de tales, minando las posibilidades de pluralismo de las democracias representativas.

Si bien puede ser cierto que la conducción de un líder populista en un sistema democrático puede llevar a una mayor ampliación de las estructuras y las prácticas poliárquicas, también lo es que puede conducir a un régimen que limita los derechos de los ciudadanos (que no estén de acuerdo con él). Por ello, otros autores sostienen que el populismo afecta la institucionalidad y la convivencia democrática (Freidenberg, 2007), al subordinar las instituciones a las decisiones de un líder y enfrentar a los órganos del Estado entre sí; al polarizar el discurso contra los que opinan diferente o critican al proyecto, y al generar inclusión a través de prácticas de subordinación más que de empoderamiento de los ciudadanos. Estos liderazgos plantean vínculos de suma 
cero: se está totalmente a favor o totalmente en contra. No hay términos medios, lo que dificulta el ejercicio y el respeto del pluralismo político.

Estos líderes no siempre han buscado fortalecer la democracia, es decir, el régimen político según el cual los gobernantes son elegidos a través de mecanismos competitivos por los ciudadanos, y son considerados responsables por sus acciones en la esfera pública, en el marco del respeto de los derechos políticos básicos y la existencia de una serie de garantías mínimas. Por el contrario, muchas veces, esos mismos líderes han sido responsables de los enfrentamientos entre poderes del Estado, de la violación de los derechos políticos básicos, de la concentración del poder, la informalización de la política, o, incluso, de que un régimen democrático se transformara en un régimen híbrido o en un régimen autoritario. La fuerte polarización y confrontación maniquea que acompaña a los populismos supone el riesgo de resolverse con la ruptura de la democracia.

Uno de los mayores problemas del populismo es su fuerte dosis de personalismo. Un individuo se cree y es construido como la encarnación de los valores del pueblo y, en nombre de este, conduce la acción política, violentando con su ejercicio el funcionamiento de las instituciones que regulan la convivencia democrática (la separación de los poderes, los mecanismos de control y regulación política). Incluso esas instituciones son vistas por el líder como impedimentos para que la voluntad popular encarnada en su figura se exprese. Por esto, los líderes populistas se sienten prisioneros de la institucionalidad y continuamente la rompen, como ha sido el caso de Velasco Ibarra, Bucaram o Correa.

Si bien la gente participa y se moviliza (tras el llamado del líder) se confunde la deliberación con la aclamación plebiscitaria del líder. En ese sentido, aunque son momentos de cambio institucional, no siempre esos cambios suponen un mayor respeto a la separación de poderes, a los partidos políticos, al ejercicio de la oposición o a los mecanismos de accountability (rendición de cuentas). La desconfianza de los populistas en las instituciones lleva a un debilitamiento del pluralismo político o al diseño de instituciones a la medida de sus líderes (y su proyecto político), aun cuando su participación está condicionada al libre ejercicio de esa competencia democrática para poder ejercer su liderazgo.

El populista defiende el derecho a ejercer el voto en un amplio marco de respeto de libertades. Si los sectores marginales no pudieran votar, tampoco tendría posibilidades de ganar una elección y emerger como movimiento político que busca representar "al pueblo" en su lucha con quienes creen que los oprimen. El líder populista exige, entonces, el pleno respeto de las libertades de expresión y de asociación, y el equitativo acceso a los medios de comunicación, ya que sin estos no tendría plataforma de lanzamiento ni espacio desde donde arengar a las masas. Lo que no queda muy claro es hasta qué punto el líder populista respeta que los que le hacen oposición ejerzan esos derechos, una vez que él está en el poder, algo que se ha podido ver en los Gobiernos de Bucaram o Correa.

Las elecciones son, para el populista, un instrumento que desintegra la unidad del 
pueblo al fragmentar la voluntad colectiva en votos individuales. El pueblo es idealizado y adquiere dimensiones infinitas. El individuo se funde en el pueblo, desconociendo cualquier mecanismo de control de sus actuaciones, $\mathrm{o}$ empleándolo como un mecanismo plebiscitario de renovación de la relación con sus seguidores. La idea de democracia, que los líderes populistas defienden, privilegia la calle frente a las instituciones; los discursos centrados en la redención del pueblo; los actos masivos que permiten escenificar el ritual discursivo frente a la discusión programática. Es una política que se da en el plano simbólico y que no cree en la idea de representación liberal.

Los líderes populistas ecuatorianos, como otros, han sido antiindividualistas, colectivistas y antiliberales en términos políticos, aunque hayan conseguido incorporar a los individuos (o ha generado la idea de que los han incorporado simbólica y materialmente al sistema político) a través del respeto de derechos concretos o de mitos y símbolos que mejoran su credibilidad en el sistema. Al mismo tiempo, estos liderazgos populistas han dividido a la sociedad a través de su distinción maniquea entre sectores populares y oligárquicos (Bucaram) o entre política tradicional y nueva política (Correa), bajo un discurso de confrontación social.

Estos líderes ecuatorianos no han estado solos. Junto al líder populista, siempre ha habido votantes populistas, que han elegido tener un vínculo directo y emocional con él, al mismo tiempo que desconfían de los partidos tradicionales y de las instituciones de la democracia representativa para resolver sus problemas cotidianos. Prefieren la repre- sentación delegativa antes que la democracia pluralista. Por tanto, la manera en que se ejerce ese liderazgo y las razones que llevan a los ciudadanos a legitimar este modo de inclusión subordinada a la voluntad del líder es clave para comprender el funcionamiento de la democracia.

\section{REFERENCIAS}

Aboy Carlés, G. (2011). El populismo entre la ruptura y la integración. Praga: II Conferencia Internacional sobre Populismo en América Latina, Centro de Estudios Iberoamericanos de la Universidad Metropolitana.

Burbano de Lara, F. (ed.) (1998). El fantasma del populismo. Aproximación a un tema (siempre) actual. Caracas: Nueva Sociedad.

Burbano de Lara, F. (comp.) (2003). Democracia, gobernabilidad y cultura política. Quito: Flacso.

Canovan, M. (1999). Trust the People! Populism and the two faces of Democracy. Political Studies, 47 (1), 2-16.

Conaghan, C. (2008a). Ecuador: Correa's plebiscitary democracy. En Diamond, L., Plattner, M. y Abente, D. (eds.). Latin America's Struggle for Democracy (pp. 199-217). Baltimore: The Johns Hopkins University Press.

Conaghan, C. (2008b). Bucaram en Panamá: las secuelas del populismo en Ecuador. En De la Torre, C. y Peruzzotti, E. (eds). El retorno del pueblo. Quito: Flacso.

Conaghan, C. y De la Torre, C. (2008). The Permanent Campaign of Rafael Correa: Making Ecuador's Plebiscitary Presidency. International Journal of Press/Politics (13), 267-284.

Corral, F. et al. El período de la nueva institucionalidad. En Corral, F. Testigo del Siglo. El Ecuador vis- 
to desde el diario El Comercio (pp. 186-193). Quito: El Comercio.

Cueva, A. (1988). El proceso de dominación política en el Ecuador. Quito: Sudamericana.

De la Torre, C. (1994). Los significados ambiguos de los populismos latinoamericanos. En Álvarez Junco, J. y González Leandri, R. (eds.). El populismo en España y América Latina. Madrid: Catriel.

De la Torre, C. (1996). Un solo toque. Populismo y cultura politica en Ecuador. Quito: CAAP.

De la Torre, C. (1998). Populismo, cultura política y vida cotidiana en Ecuador. En Burbano de Lara, F. (ed.). El fantasma del populismo. Aproximación a un tema (siempre) actual. Caracas: Nueva Sociedad.

De la Torre, C. (1999). Neopopulism in Contemporary Ecuador: The Case of Bucaram's Use of the Mass Media. International Journal of Politics, Culture and Society, 12 (4), 555-571.

De la Torre, C. (2000). The Populist Seduction in Latin America: The Ecuadorian Experience. Athens: Ohio University Press.

De la Torre, C. (2009). Democracia, participación y representación populista en Ecuador. En Tanaka, M. (ed.). La nueva coyuntura critica en los paises andinos. Lima: International IDEA.

De la Torre, C. (2012). Rafael Correa, un populista del siglo xxi. Recuperado de: http://lanic.utexas. edu/project/etext/llilas/vrp/delatorre.pdf

Edelman, M. (1964). Constructing the Political Spectacle. Chicago: The Chicago University Press.

Fernández, I. y Ortiz, G. (1988). ¿La agonía del populismo? Quito: Editorial Plaza Grande.

Freidenberg, F. (2003). Jama, Caleta y Camello. Las estrategias de Abdalá Bucaram y el PRE para ganar elecciones. Quito: Corporación Editora Nacional.

Freidenberg, F. (2007). La tentación populista: una vía al poder en América Latina. Madrid: Síntesis.
Freidenberg, F. (2008a). El sueño frustrado de la gobernabilidad: instituciones, actores y politica informal en Ecuador. Barcelona: Documento CIDoB.

Freidenberg, F. (2008b). Correazos, cholocracia, populismo religioso e ingobernabilidad en Ecuador. En Dabène, O. (ed.). L'Amérique Latine aux urnes (pp. 215-236). Paris: Presses de Sciences Po.

Freidenberg, F. (2008c). El Flautista de Hammelin: liderazgo y populismo en la democracia ecuatoriana. En De la Torre, C. y Peruzzotti, E. (eds.). El retorno del pueblo. Quito: Flacso.

Freidenberg, F. (2012). ¿Qué es el populismo? Enfoques de estudio y una nueva propuesta de definición como un estilo de liderazgo. En Dubesset, E. y Majlatova, L. (eds.). El populismo en Latinoamérica: teoría, historia y valores. Francia: Presses Universitairess de Bordeaux.

Guerrero Burgos, R. (1994). Regionalismo y democracia social en los origenes del 'CFP'. Quito: Centro Andino de Acción Popular.

Hurtado, O. (1999). El poder politico en el Ecuador. Quito: Planeta-Letraviva.

Ibarra, H. (2004). El populismo en la política ecuatoriana contemporánea. En Weyland, K., De la Torre, C., Aboy Carlés, G. y Ibarra, H. Releer lospopulismos. Quito: Centro Andino de Acción Popular; Serie Diálogos.

Laclau, E. (2005). La razón populista. México: Fondo de Cultura Económica.

Martz, J. (1980). The Regionalist Expression of Populism: Guayaquil and the CFP, 1948-1960. Journal of Interamerican Studies and World Affairs (22), 289-314.

Martz, J. (1983). Populist Leadership and the Party Caudillo: Ecuador and the CFP, 1962-1981. Studies in Comparative International Development, 18 (3), 22-49. 
Mejía Acosta, A. (2002). Gobernabilidad democrática. Quito: Fundación Konrad Adenauer.

Menéndez Carrión, A. (1986). La conquista del voto. Quito: Corporación Editora Nacional.

Moncayo, M. P. (2010). Una democracia de rostro populista. Ecuador Debate (80), 121-135.

Moreano, H. y Donoso, C. (2006). Populismo y Neopopulismo en Ecuador. Revista Opera, 6 (006), 117-140.

O’Donnell, G. (1992). ¿Democracia delegativa?. Cuadernos del CLAEH, 17 (61), 9-19.

Panizza, F. (2001). Más allá de la "democracia delegativa". La vieja política y la "nueva economía". En Cheresky, I. y Pousadela, I. (comps.). Politica e Instituciones en las nuevas democracias latinoamericanas. Buenos Aires: Paidós.
Panizza, F. (2008). Fisuras entre populismo y democracia en América Latina. Stockholm Review of Latin American Studies (3), 81-92.

Pachano, S. (2007). La trama de Penélope: procesos politicos e instituciones en Ecuador. Quito: Flacso.

Quintero, R. (1978). El mito del populismo en el Ecuador. Análisis de los fundamentos del Estado Moderno, 1895-1934. Quito: Flacso.

Quintero, R. (2005). Electores contra partidos en un sistema politico de mandos. Quito: Abya-Yala.

Recalde, P. (2007). Elecciones presidenciales 2006: una aproximación a los actores del proceso. Revista Iconos, 27, 15-25.

Worsley, P. (1970). El populismo como concepto. En Ionescu, G. y Gellner, E. (eds.). Populismo: sus significados y caracteristicas nacionales. Buenos Aires: Amorrortu. 